\title{
PERIFERINĖS PERFUZIJOS VERTINIMO REIKŠME் KLINIKINĖJE PRAKTIKOJE
}

\author{
Andrius Pranskūnas ${ }^{1}$, Erika Šalčiūtè ${ }^{2}$ Živilè Pranskūniené $\dot{e}^{3}$, Neringa Balčiūnienè ${ }^{1}$, \\ Edvin Šneider ${ }^{1}$ \\ ${ }^{1}$ Lietuvos sveikatos moksly universiteto Intensyviosios terapijos klinika, \\ ${ }^{2}$ Lietuvos sveikatos mokslu universiteto Medicinos fakultetas, \\ ${ }^{3}$ Lietuvos sveikatos moksly universiteto Vaistu technologijos ir socialinès farmacijos katedra
}

Raktažodžiai: periferinè perfuzija, neinvazinis vertinimas, subjektyvus klinikinis vetinimas, kapiliaru prisipildymo laikas, temperatūros gradientas, periferinès perfuzijos indeksas

\begin{abstract}
Santrauka
Periferinès perfuzijos monitoravimas yra paremtas koncepcija, kad šoko metu kraujotaka anksčiausiai pablogeja periferiniuose audiniuose, o gydymo metu jų kraujotaka atsistato vèliausiai. Stebint odos ir raumenų perfuziją galima anksti įtarti sisteminès kraujotakos blogejjimą. Šiame straipsnyje apžvelgème nesudètingus, klinikinejje praktikoje dažniausiai naudojamus neinvazinius periferinès perfuzijos vertinimo metodus bei pateikeme klinikinius tyrimus, kuriais vertinamas šių metodų ryšys su baigtimis ir organų funkcijos pokyčiais.
\end{abstract}

\section{Ivadas}

Svarbiausias kraujotakos stebejjimo tikslas yra kuo anksčiau nustatyti nepakankamą audinių perfuziją bei ịsotinimą deguonimi. Tai padeda anksčiau pradèti gydymą ir taip išvengti organų pažeidimo. Klinikinèje praktikoje audinių perfuzija ir įsotinimas deguonimi dažniausiai vertinami atsižvelgiant i ịprastinių sisteminių rodiklių, pvz., arterinio kraujospūdžio, arterinio kraujo sudèties, laktatų rodmenis. Tačiau sisteminès kraujotakos rodmenys neturi sąsajos su laktatų kiekiu kraujyje ir organų mikrocirkuliacijos būkle $[1,2]$. Be to, sisteminès kraujotakos tyrimams dažnai naudojami invaziniai metodai, kurie atliekami tik intensyviosios terapijos skyriuje ir užima daug laiko. Atsižvelgiant ị šiuos trūkumus ieškoma būdų, kaip tiksliai ir greitai ịvertinti audinių kraujotaką ir įsotinimą deguonimi.

Šoko metu kraujotaka yra nukreipiama nuo mažiau svarbių organų (pvz., odos, raumenų) link gyvybiškai svarbių (širdis, smegenys, inkstai). Monitoruojant perfuziją mažiau gyvybei reikšminguose audiniuose galima anksti nustatyti pablogejusią perfuziją gyvybiškai svarbiuose audiniuose. Periferinès perfuzijos stebejjimas gali būti paremtas koncepcija, kad šoko metu kraujotaka anksčiausiai pablogeja periferiniuose audiniuose, o gydymo metu jų kraujotaka atsistato véliausiai [3]. Oda ir skersaruožiai raumenys yra funkciškai ir metaboliškai skirtingi organai, tačiau jų kraujotaka turi panašumų. Šių organų kraujotaką vidutiniškai arba stipriai veikia simpatiniai vazokonstrikciniai mechanizmai, o autoreguliacija yra silpna. Vainikiniu širdies kraujagyslių, smegenų ir inkstų kraujotakai būdinga aukšto laipsnio autoreguliacija ir silpna simpatinè kontrolè. Žinoma, kad tiek hipodinaminès, tiek ir hiperdinaminès eigos šoko metu gali pasireikšti pablogejusios periferinès audinių perfuzijos požymiai [4]. Pablogejjusi periferinè perfuzija nustatoma klinikiniu vertinimu, odos temperatūros matavimu bei naudojant optinius prietaisus. Šie metodai yra neinvaziniai ir nesunkiai atliekami prie ligonio lovos. Kyla klausimas, ar periferinès perfuzijos tyrimui naudojami neinvaziniai metodai turi prognostinę reikšmę.

Pagrindinis mūsų tikslas šiame straipsnyje yra apibūdinti nesudètingus, dažniausiai naudojamus neinvazinius periferinès perfuzijos vertinimo metodus klinikineje praktikoje bei apžvelgti klinikinius tyrimus, kuriais vertinamas šių metodų ryšys su baigtimis ir organų funkcijos pokyčiais.

\section{Tyrimo medžiaga ir metodai}

Pasirinkti 1969-2014 metais publikuoti klinikiniai tyrimai su žmonėmis (pacientais), kurių būklė buvo kritinė. Straipsnių paieška atlikta Pubmed, Google scholar duomenų bazèse. Paieškoje naudoti raktažodžiai anglų kalba: peripheral perfusion, noninvasive monitoring, subjective clinical assessment, temperature gradients, peripheral perfusion index, near infrared spectroscopy, critically ill.

Klinikinis periferinès perfuzijos vertinimas. Peri- 
1 lentelè. Periferinès perfuzijos vertinimo metodai KPL, kapiliaru prisipildymo laikas; NIRS, artimosios srities infraraudonuju spinduliu spektroskopija; PPI, periferinès perfuzijos indeksas

\begin{tabular}{|c|c|c|c|}
\hline Metodas & Privalumai & Trūkumai & $\begin{array}{l}\text { Ryšys } \\
\text { su } \\
\text { miršta- } \\
\text { mumu }\end{array}$ \\
\hline $\begin{array}{l}\text { Subjektyvus } \\
\text { odos tempe- } \\
\text { ratūros verti- } \\
\text { nimas }\end{array}$ & $\begin{array}{l}\text { Lengvai } \\
\text { atliekamas }\end{array}$ & $\begin{array}{l}\text { Subjektyvus. } \\
\text { Netinka pacientams, } \\
\text { kuriems yra } \\
\text { periferinių } \\
\text { kraujagyslių } \\
\text { okliuzinė liga. } \\
\text { İtakos turi aplinkos } \\
\text { temperatūra. }\end{array}$ & Yra \\
\hline $\begin{array}{l}\text { Odos } \\
\text { margumo } \\
\text { vertinimas }\end{array}$ & $\begin{array}{l}\text { Lengvai } \\
\text { atliekamas }\end{array}$ & $\begin{array}{l}\text { Netinka } \\
\text { juodaodžiams }\end{array}$ & Yra \\
\hline KPL & $\begin{array}{l}\text { Lengvai } \\
\text { atliekamas }\end{array}$ & $\begin{array}{l}\text { Turi ịtakos aplinkos, } \\
\text { odos ir vidinè kūno } \\
\text { temperatūra, apšvie- } \\
\text { timas }\end{array}$ & Yra \\
\hline $\begin{array}{l}\text { Kūno tempe- } \\
\text { ratūros gradi- } \\
\text { entai: vidinės } \\
\text { ir kojos nykš- } \\
\text { čio, dilbio ir } \\
\text { piršto }\end{array}$ & $\begin{array}{l}\text { Validuoti odos } \\
\text { kraujotakos } \\
\text { tyrimo metodai }\end{array}$ & $\begin{array}{l}\text { Naudojami mažiau- } \\
\text { siai du temperatūros } \\
\text { davikliai; sunku } \\
\text { vertinti hipotermijos } \\
\text { atveju }\end{array}$ & Yra \\
\hline PPI & $\begin{array}{l}\text { Nustatomas } \\
\text { pulsoksimetri- } \\
\text { jos metu, realiu } \\
\text { laiku rodo peri- } \\
\text { ferinių krauja- } \\
\text { gyslių vazomo- } \\
\text { torinio tonuso } \\
\text { pokyčius }\end{array}$ & $\begin{array}{l}\text { Netikslus, kai paci- } \\
\text { entas juda; matuoja- } \\
\text { mas ant piršto }\end{array}$ & Yra \\
\hline NIRS & $\begin{array}{l}\text { Neinvazinis } \\
\text { optinis meto- } \\
\text { das; perfuzija } \\
\text { gali būti matuo- } \\
\text { jama ịvairiose } \\
\text { vietose }\end{array}$ & $\begin{array}{l}\text { İvairios prietaisu } \\
\text { modifikacijos, krau- } \\
\text { jagyslių okliuzijos } \\
\text { testas nėra standarti- } \\
\text { zuotas. Rodmenims } \\
\text { reikšmės turi odos } \\
\text { storis, riebalinio au- } \\
\text { dinio storis, edemos }\end{array}$ & Yra \\
\hline
\end{tabular}

ferinę kraujotaką galima lengvai ịvertinti atliekant fizinę paciento apžiūrą, kurios metu liečiamasi prie ligonio odos ir matuojamas kapiliarų prisipildymo laikas. Klinikiniai nenormalios kraujotakos odoje požymiai yra šalta, blyški, prakaituota ir marga oda, taip pat pailgèjęs kapiliarų prisipildymo laikas (1 lentelè).

Subjektyvus odos temperatūros vertinimas. Odos tem- peratūra yra vertinama kambario temperatūroje tyrèjui priglaudžiant dorsalini jo plaštakos ar pirštu paviršių (ši plaštakos dalis jautriausia temperatūros pokyčiams) paeiliui prie visų keturių paciento galūnių. Subjektyviai galūnès gali būti šaltos arba šiltos. Pacientas turi šaltas galūnes, jei vertintojo nuomone visos galūnès yra šaltos arba šaltos tik apatinès galūnès, neatsižvelgiant $i$ šiltas viršutines galūnes [5]. Toks vertinimas netinka pacientams, kuriems yra periferinių kraujagyslių okliuzinè liga. Besikeičiant odos temperatūrai, taip pat ir subjektyviam jos pojūčiui, kartu keičiasi objektyvūs odos kraujotakos rodmenys tiek sveikiems, tiek ir pacientams, kurie yra kritinëje būklëje [6, 7]. Piršto galiuko temperatūra taip pat koreliuoja su objektyviais piršto galiuko kraujotakos rodmenimis [8]. Tyrimai rodo, kad subjektyviai šaltos galūnès yra susijusios su mažesniu minutiniu širdies tūriu, didesniu laktatų kiekiu[5, 9] bei blogesne organų funkcija[9] pacientams, kurie gydomi intensyviosios terapijos skyriuje (tarp jų yra pacientų, kuriems yra sepsis). Be to, šaltos ir prakaituotos galūnès yra susijusios su didesniu pacientu, kuriems yra kardiogeninis šokas, mirštamumu [10].

Subjektyviam ligonio odos temperatūros vertinimui gali turèti ịtakos aplinkos temperatūra. Toks vertinimas turètų būti atliekamas kambario temperatūros sąlygomis $\left(22^{\circ} \mathrm{C}\right)$. Taip pat įtakos gali turèti periferinių kraujagyslių okliuzinè liga.

Odos margumas. Odos margumas yra lengvai atpažistamas požymis, kuris gali pasireikšti pacientams, kurie yra kritinèje būklëje. Odos margumas (angl. mottling) - tai melsvų odos dèmių plitimas, kuris dažniausiai prasideda kelių ar alkūnių srityje. Jis atsiranda dèl heterogeninès mikrokraujagyslių vazokonstrikcijos ir rodo nenormalią odos perfuziją. Medicinos vadovèliuose teigiama, kad odos margumas yra šoko požymis. Daugiau kaip prieš 40 metų V.Vic-Dupont ir kolegos[11] apraše pacientų, kuriems yra sepsinis šokas, klinikinius požymius, iš kurių odos margumas kelio srityje pasireiškej 65 proc. pacientų. Visai neseniai H.Ait-Outfella ir kolegos[12], siekdami objektyviai vertinti odos margumą, sukūrè objektyvią skalę, kuri paremta margumo ploto, besitęsiančio nuo kelio centro link periferijos, vertinimu (1 pav.). Taigi, šios skalès pagalba galima apibūdinti margumo plitimą nuo kelio link periferijos balais nuo 0 iki 5: 0 - margumo nèra; 1 - mažas (monetos dydžio) margas plotelis kelio centre; 2 - margumas neišplitęs už viršutinès girnelès ribos; 3 - margumas išplitęs ne toliau kaip šlaunies vidurys; 4 - margumas išplitęs ne toliau kaip kirkšnies raukšlè; 5 - margumas išplitęs už kirkšnies raukšlès ribų. Ši mokslininkų grupe nustatè, kad kuo didesnis margumo balas per pirmas 6 valandas nuo gydymo pradžios, tuo didesnis pacientų, kuriems yra sepsi- 
nis šokas, 14-os dienų mirštamumas. Margumo balo didejjimas turi ryši su laktatų kiekiu kraujyje didejjimu, diurezès mažejimu bei organų funkcijos blogejjimu. Margumo skalè neturi ryšio su sisteminès hemodinamikos pokyčiais. Margumo skalę lengva išmokti, yra mažas vertinimo variabilumas tarp tyrèjų, todèl gali būti naudojama klinikinès apžiūros metu. Šio metodo trūkumas yra tas, jog jis negali būti pritaikomas juodaodžiams pacientams.

Kapiliary prisipildymo laikas. Kapiliarų prisipildymo laikas (KPL) - tai laikas, per kurị išorinè kapiliaru ložè atgauna ịprastą spalvą po to, kai buvo suspausta iki blyškumo. Pirmasis ši metodą aprašè H.K.Beecher su kolegomis 1947 metais [13]. Naudodami KPL skirstymą į normalų, sulètejusị ir labai lètą, jie nustate ryši su šoko buvimu bei jo sunkumu. 1981 m. H.R.Champion ir kolegos[14] ịtrauke KPL ị traumos vertinimo skalę, jo normalia verte laikydami mažiau nei 2 sekundes. Nuo to laiko KPL vis plačiau naudojamas suaugusių ir vaiku specializuotos pagalbos algoritmuose kaip greitas ir struktūrinis kraujotakos vertinimo komponentas. Toliau vyksta diskusija dèl KPL normos ribų, faktorių, galinčių turèti įtakos jo rodmenims bei matavimų validumo.

D.L.Shriger ir L.Baraff [15] nustatè, kad sveikų žmonių KPL viršutinè normos riba yra susijusi su amžiumi ir gali siekti 4,5 sek. Naujagimiams norma yra iki 3 sek., vaikams - iki 2 sek., suaugusiems vyrams normali verte taip pat yra iki 2 sek., moterims - iki 2,9 sek. Tuo tarpu senyvo amžiaus žmonems kapiliarų prisipildymo laikas gali būti vertinamas kaip normalus, jei jis yra ne ilgesnis kaip 4,5 sek.

Atlikti klinikiniai tyrimai parodè, kad yra koreliacija tarp KPL ir dehidracijos laipsnio vaikams, kuriems yra diarèja. KPL nuo 1,5 iki 3,0 sek. yra susijęs su $50-100 \mathrm{ml} / \mathrm{kg}$ skysčių trūkumu, o KPL > 3 sek. rodo didesnị kaip 100 $\mathrm{ml} / \mathrm{kg}$ skysčiu deficitą [16]. Vaikams prailgèjęs KPL, t.y. $>2$ sek., rodo dehidraciją $\geq 5$ proc. kūno svorio [17]. KPL didesnis kaip 2 sek. yra vienas iš stipriausių ir ankstyvų sunkios infekcijos (sepsio) vaikams rodmenų ambulatorinèmis sąlygomis [18]. Taip pat nustatyta, kad vaikams KPL $\leq 2$ sek. yra susijęs su viršutinès tuščiosios venos deguonies saturacija $\geq 70$ proc. [19].

A.Lima ir kolegų[9] atliktas tyrimas parodè, kad inten- syvios terapijos skyriuje pirmas 24 val. gydomų suaugusių pacientų KPL didesnis kaip 4,5 sek yra susijęs su audinių hipoperfuzija. Per pirmas 24 val. intensyvaus gydymo KPL vertinimas padeda atskirti pacientus, kuriems yra sunkesnis organų funkcijos nepakankamumas. KPL $>4,5$ rodo ne tik ryši su sumažejusia audinių perfuzija, bet ir didesnę organų funkcijos blogejjimo tikimybę per kitas dienas palyginti su pacientais, kurių KPL yra normalus. Nors nemažo matavimų variabilumo tarp atskiru tyrejų buvimas išlieka diskusijų objektu, KPL viršutinè normos riba 4,5 sek. yra reikšmingas rodmuo pacientams, kurie gydomi intensyviosios terapijos skyriuje pirmas 24 val.

Aplinkos, odos ir vidinè kūno temperatūra turi ịtakos KPL. Todèl KPL matavimai turètų būti atliekami patalpoje, kurios oro temperatūra yra pastovi, apie $22{ }^{\circ} \mathrm{C}$. Patalpa turi būti gerai apšviesta, nes prieblandoje galimi klaidingi vertinimai [20]. Tiriamojo ranka pakeliama iki širdies lygio. Tyrejjas suspaudžia tiriamojo piršto nagą (suaugusiems dažniausiai rankos rodomojo piršto nagą) ir atleidžia, ijungia laikmatị ir pamatuoja laiką, per kurị nago guolis atgauna ịprastą spalvą. Vis dar diskutuojama, kurị pirštą ar kurią vietą reikètų naudoti matavimams, kokiu stiprumu ir kiek laiko laikyti suspaudus. Daugumoje tyrimų buvo taikytas vidutinio stiprumo spaudimas 15,5 ar 3 sek.

Naujagimiams ir jaunesniems vaikams KPL matavimas spaudžiant kaktos vidurị ar krūtinkaulị yra paprastesnis ir gali būti tikslesnis, nei spaudžiant kulną, delną ar pirštą [19, 21]. Pasaulio sveikatos organizacija rekomenduoja matavimams naudoti rankos ar kojos nykščio nagą. Klinikinejje praktikoje vaikų KPL matavimui dažniausiai spaudžiama rankos piršto distalinè dalis arba nago guolis, krūtinkaulis [22].

Kūno temperatūros gradientas. Odos temperatūra yra lengvai ir neinvaziškai nustatomas rodiklis. M.H.Weil ir kolegos [23] 1969 m. nustatė, kad kojos nykščio temperatūra turi ryšį su mirštamumu pacientams, kuriems yra šokas. Vèliau tyrejjai parode, kad kūno temperatūros gradientai geriau atspindi odos kraujotakos pokyčius negu vienos srities temperatūra [24, 25]. Kūno temperatūros gradientas - tai temperatūros skirtumas tarp dviejų matuojamų vietų, pvz., kūno periferijos ir aplinkos, centrinès ir kojos nykščio, dilbio ir piršto galo. Šoko metu vazokonstrikcija lemia odos temperatūros mažèjimą. Tokiu būdu mažèja vidinès šilumos atidavimas ị periferiją, didèja vidinè temperatūra bei didèja vidinès ir periferinès temperatūros gradientas. Periferinè temperatūra matuojama temperatūros davikliu, kuris tvirtinamas ant ventralinio kojos nykščio paviršiaus. Ši vieta yra patogi periferinès temperatūros matavimui dèl menkos vietinès šilumos gamybos ir pakankamo atstumo nuo kitų prietaisų, galinčių turèti įtakos rodmenims. 
Pacientams, kuriems yra stabili hemodinamika, būdingas $3-7^{\circ} \mathrm{C}$ vidinès ir kojos nykščio temperatūros gradientas. Hipotermija ir šalta aplinka $\left(<20^{\circ} \mathrm{C}\right)$ riboja vidinès ir kojos nykščio temperatūros gradiento naudojimą.

Odos ir kūno temperatūros kitimas chirurginių operacijų metu, ypač tų, kurių metu naudojama dirbtinė kraujo apytaka, dèl operacinès aplinkos poveikio apsunkina periferinès perfuzijos vertinimą naudojant temperatūros gradientą. Tokiu atveju labiausiai tinkamas yra dilbio ir rankos piršto galo temperatūros gradiento naudojimas, nes jo matavimas yra paremtas prielaida, kad dilbis yra veikiamas ta pačia aplinkos temperatūra kaip ir piršto galas $[25,26]$. Besikeičianti aplinkos temperatūra panašiai veikia tiek dilbị, tiek ir piršto galą ir mažai veikia gradiento pokyčius. Piršto temperatūra matuojama temperatūros davikliu, kuris fiksuojamas ant ventralinio rankos piršo (dažniausiai rodomojo piršto) paviršiaus. Dilbio temperatūros daviklis fiksuojamas ant stipinkaulinio dilbio paviršiaus, viduryje tarp alkūnès ir riešo. Dilbio ir piršto gradientas didesnis kaip 0 rodo vazokonstrikciją, o $\geq 4$ - sunkią vazokonstrikciją [26]. Dilbio ir piršto temperatūros gradiento vertinimas kartu su klinikiniu tyrimu padeda patikimai nustatyti pablogejjusią periferinę perfuziją.

Optiniai metodai. Optines sistemas naudojantys prietaisai ị audinius skleidžia skirtingų bangos ilgių šviesą, kad nustatytų audinių kraujotaką ar/ir įsotinimą deguonimi. Dažniausiai klinikineje praktikoje naudojami monitoriai, kurie geba nustatyti periferinę perfuziją ar/ir ịsotinimą deguonimi prie ligonio lovos, yra piršto fotopletizmografija ir artimosios srities infraraudonujų spindulių spektroskopija.

Artimosios srities infraraudonuju spinduliu spektroskopija. Artimosios srities infraraudonujų spindulių spektroskopija (angl. Near-infrared spectroscopy (NIRS) yra metodas, kuriuo, naudojant artimosios srities infraraudonuosius spindulius, audinyje matuojami chromoforai (oksi- ir deoksihemoglobinas, mioglobinas ir citochromas aa3). Oksi- ir deoksihemoglobino frakcijos yra naudojamos audinio icsotinimui deguonimi $\left(\mathrm{StO}_{2}\right)$ apskaičiuoti. Be to, pagal šviesos absorbciją apskaičiuojamas bendras audinio hemoglobino $(\mathrm{HbT})$ ir absoliutus audinio hemoglobino indeksas (THI), kurie rodo kraujo tūrị mikrokraujagyslèse uždèto elektrodo srityje. NIRS signalas sunkiau patenka ị kraujagysles, kurių skersmuo mažesnis negu $1 \mathrm{~mm}$ (arterioles, venules, kapiliarus). Kadangi 75 proc. kraujo skersaruožiuose raumenyse yra veninio, NIRS $\mathrm{StO}_{2}$ rodmuo rodo vietini veninį hemoglobino įsotinimą deguonimi. Šis metodas rodo bendrą $\mathrm{StO}_{2}$ audiniuose ir netinka būklèms, kurių metu yra heterogenine kraujotaka [27]. NIRS nerodo mikrokraujagyslių kraujotakos. Sepsio metu $\mathrm{StO}_{2}$ skiriasi nuo $\mathrm{ScvO}_{2}$. Kartu atliekamas vazoreaktyvumo testas labiau parodo mikrokraujagyslių galèjimą padidinti funkcionalumą negu realią jų perfuziją [28]. NIRS rodmenims reikšmès turi odos storis, riebalinio audinio storis, edemos, todèl matuoti naudojamas elektrodas fiksuojamas delne ant nykščio pakylos, nes toje vietoje odos storiui ir riebaliniam audiniui, esančiam apie raumenį, mažiau įtakos daro skysčiu perteklius ar svorio prieaugis [29]. N.I.Shapiro ir kolegos[30] nustatè, kad dinaminiai NIRS rodmenys turi ryšį su organų funkcijos blogejimu ir mirštamumu pacientams, kuriems yra sepsinis šokas. G.Colin ir kolegos[31] tyrė $\mathrm{StO}_{2}$ pokyčius skirtingose kūno vietose pacientams, kuriems yra sunkus sepsis, pirmas 6 gydymo valandas. Jie nustate, kad $\mathrm{StO}_{2}$ matavimas m.masseter srityje turi geresnę prognostinę reikšmę, geriau atspindi gydymo poveikį, palyginti su matavimais nykščio pakylos srityje. Temperatūros ir vazoaktyvių medikamentų itaka šiam metodui pilnai neištirti.

Periferinés perfuzijos indeksas. Periferinès perfuzijos indeksas (PPI) yra apskaičiuojamas iš pulso oksimetro fotoelektrinio pletizmografinio signalo. Pulso oksimetrijos metu matuojamas arterinio kraujo hemoglobino ịsotinimas deguonimi ir pulso dažnis. Šis neinvazinis monitorius naudoja du šviesos bangos ilgius, raudonaji ir infraraudonaji, kurie skleidžiami pro distalinę piršto dalį. Tokiu būdu monitoriuje mes galime stebèti pulsuojančią pletizmografinę bangą. Iš pletizmografinès bangos galima apskaičiuoti daug rodiklių. PPI yra santykis tarp pulsuojančios ir nepulsuojančios kreivès dalių, išreikštas procentais. Vazodilatacija didina pulsuojančios kreivès dalies didį, o vazokonstrikcija - mažina [32, 33]. Todèl PPI pokyčiai rodo periferinio vazomotorinio tono pokyčius. A.Lima ir kolegų[34] tyrimas parodè, kad sveikų savanorių PPI mediana yra 1,4 proc. Pacientams, kurie yra kritinèje būklèje ir gydomi intensyviosios terapijos skyriuje, ribinis PPI rodmuo 1,4 proc. padeda nustatyti pablogejusią periferinę perfuziją $[9,34]$. PPI turi ryši su organų funkcijos blogejjimu bei mirštamumu [35].

Periferinès perfuzijos gydymo reikšmė. Tyrimai rodo, kad sisteminès hemodinamikos pokyčiai neturi ryšio su periferinès perfuzijos pokyčiais tiek sveikiems, tiek ir pacientams, kurie yra kritinejje būklèje [35, 36]. Kita vertus, išliekanti pablogejjusi periferinè perfuzija yra susijusi su blogesne organų funkcija ir didesniu mirštamumu [9, 35]. Taigi, priemonès, kurios gerintų periferinę perfuziją, turètų gerinti organų funkciją ir didinti tokių pacientų išgyvenamumą.

E.Futier ir kolegos[37] nustatè, kad bandomoji skysčių infuzija (angl. fluid challenge) gerina periferinę perfuziją pacientams, kuriems atliekama didelès apimties pilvo chirurgija. G.Hernandez ir kolegų[38] atliktas tyrimas parodé, kad ankstyvas periferinès perfuzijos gerejjimas yra susijęs su normaliu laktatų kiekiu po 24 val. gydymo pacientams, 
kuriems yra sunkus sepsis ar sepsinis šokas. Iš tirtų periferinès perfuzijos rodiklių (KPL, vidinès ir kojos nykščio temperatūros gradiento, dilbio ir piršto galo temperatūros gradiento, subjektyvaus odos temperatūros vertinimo) KPL normalizavosi anksčiausiai. C.A.Den Uil ir kolegos[39] nustate, kad nitroglicerino infuzija priklausomai nuo dozès gerina periferinę perfuziją pacientams, kuriems yra sunkus širdies nepakankamumas ar kardiogeninis šokas. Tai rodo ne tik kartotinio periferinès perfuzijos vertinimo svarbią reikšmę, bet ir būtinumą reguliarų periferinès perfuzijos vertinimą ịtraukti ị pacientų, kuriems yra šokas, gydymo stebejjimo strategiją.

Kad mikrokraujagyslių (arteriolių, kapiliarų, venulių) perfuzija pablogejusi, galima ịtarti iš pablogejjusios periferinès perfuzijos požymių, pvz., margos odos, pailgèjusio KPL, padidejjusio vidinès ir kojos nykščio arba dilbio ir piršto temperatūros gradientų. Šie pablogejjusios odos perfuzijos požymiai yra mažai specifiški ir jautrūs, todèl nustatyti vidaus organų mikrocirkuliacijos pablogejjimą yra sunku. Odos vazokonstrikcija yra fiziologinè reakcija ị sumažèjusị minutinị širdies tūrị, siekiant nukreipti sisteminę kraujotaką i gyvybiškai svarbius organus. E.C.Boerma ir kolegu [40] atliktas klinikinis tyrimas nerado koreliacijos tarp vidinès ir kojų temperatūros gradiento ir kapiliaru perfuzijos, nustatytos tamsaus lauko kraštinio srauto (angl. sidestream dark field (SDF) videomikroskopijos metodu poliežuvyje pacientams, kuriems yra sunkus sepsis arba sepsinis šokas. Todèl galima teigti, kad klinikiniai odos perfuzijos požymiai rodo kraujotakos sutrikimo sunkumą ir susiję su bloga baigtimi, bet neteikia informacijos apie organų mikrocirkuliaciją.

\section{Išvados}

Periferinès kraujotakos pokyčiai gali anksti parodyti sisteminès kraujotakos pokyčius. Periferinès perfuzijos tyrimas yra neinvazinis ir lengvai atliekamas prie ligonio lovos. Periferinès perfuzijos rodikliai turi ryši su blogesne organu funkcija ir didesniu mirštamumu, tačiau nerodo organų mikrocirkuliacijos.

\section{Literatūra}

1. De Backer D, Creteur J, Preiser JC, Dubois MJ, Vincent JL. Microvascular blood flow is altered in patients with sepsis. Am J Respir Crit Care Med. 2002 Jul 1;166(1):98-104.

2. Pranskunas A, Pilvinis V, Dambrauskas Z, Rasimaviciute R, Planciuniene R, Dobozinskas P. et al. Early course of microcirculatory perfusion in eye and digestive tract during hypodynamic sepsis. Crit Care. 2012 May 15;16(3):R83.

3. Poeze M, Solberg BC, Greve JW, Ramsay G. Monitoring global volume-related hemodynamic or regional variables after initial resuscitation: What is a better predictor of outcome in critically ill septic patients? Crit Care Med. 2005 Nov;33(11):2494-500.

4. Bonanno FG. Clinical pathology of the shock syndromes. J Emerg Trauma Shock. 2011 Apr;4(2):233-43.

5. Kaplan LJ, McPartland K, Santora TA, Trooskin SZ. Start with a subjective assessment of skin temperature to identify hypoperfusion in intensive care unit patients. J Trauma. 2001 Apr;50(4):620,7; discussion 627.

6. Lima A, van Bommel J, Sikorska K, van Genderen M, Klijn E, Lesaffre E. et al. The relation of near-infrared spectroscopy with changes in peripheral circulation in critically ill patients. Crit Care Med. 2011 Jul;39(7):1649-54.

7. Pearson J, Low DA, Stohr E, Kalsi K, Ali L, Barker H. et al. Hemodynamic responses to heat stress in the resting and exercising human leg: Insight into the effect of temperature on skeletal muscle blood flow. Am J Physiol Regul Integr Comp Physiol. 2011 Mar;300(3):R663-73.

8. Carrillo AE, Cheung SS, Flouris AD. A novel model to predict cutaneous finger blood flow via finger and rectal temperatures. Microcirculation. 2011 Nov;18(8):670-6.

9. Lima A, Jansen TC, van Bommel J, Ince C, Bakker J. The prognostic value of the subjective assessment of peripheral perfusion in critically ill patients. Crit Care Med. 2009 Mar;37(3):934-8.

10. Hasdai D, Holmes DR,Jr, Califf RM, Thompson TD, Hochman JS, Pfisterer M. et al. Cardiogenic shock complicating acute myocardial infarction: Predictors of death. GUSTO investigators. global utilization of streptokinase and tissue-plasminogen activator for occluded coronary arteries. Am Heart J. 1999 Jul;138(1 Pt 1):21-31.

11. Vic-Dupont V, Coulaud JP, Carbon C. Le choc au cours des infections (signes et e'tiologies). les journe'es de re'animation de l'Ho^pital claude bernard. Libraries Arnette edn., Paris. 1968.

12. Ait-Oufella H, Lemoinne S, Boelle P,Y., Galbois A, Baudel J,L., Lemant J. et al. Mottling score predicts survival in septic shock. Intensive Care Med. 2011 May;37(5):801-7.

13. Beecher HK, Simeone FA. The internal state of the severely wounded man on entry to the most forward hospital. Surgery. 1947 Oct;22(4):672-711.

14. Champion HR, Sacco WJ, Carnazzo AJ, Copes W, Fouty WJ. Trauma score. Crit Care Med. 1981 Sep;9(9):672-6.

15. Schriger DL, Baraff L. Defining normal capillary refill: Variation with age, sex, and temperature. Ann Emerg Med. 1988 Sep;17(9):932-5.

16. Saavedra JM, Harris GD, Li S, Finberg L. Capillary refilling (skin turgor) in the assessment of dehydration. Am J Dis Child. 1991 Mar;145(3):296-8.

17. Steiner MJ, DeWalt DA, Byerley JS. Is this child dehydrated? JAMA. 2004 Jun 9;291(22):2746-54.

18. Van den Bruel A, Haj-Hassan T, Thompson M, Buntinx F, Mant D. European Research Network on Recognising Serious Infection investigators. Diagnostic value of clinical features at presentation to identify serious infection in children in 
developed countries: A systematic review. Lancet. 2010 Mar 6;375(9717):834-45.

19. Raimer PL, Han YY, Weber MS, Annich GM, Custer JR. A normal capillary refill time of $/=70 \%$. J Paediatr. 2011 Jun;158(6):968-72.

20. Brown LH, Prasad NH, Whitley TW. Adverse lighting condition effects on the assessment of capillary refill. Am J Emerg Med. 1994 Jan;12(1):46-7.

21. Strozik KS, Pieper CH, Cools F. Capillary refilling time in newborns--optimal pressing time, sites of testing and normal values. Acta Paediatr. 1998 Mar;87(3):310-2.

22. King D, Morton R, Bevan C. How to use capillary refill time. Arch Dis Child Educ Pract Ed. 2013 Nov 13.

23. Joly HR, Weil MH. Temperature of the great toe as an indication of the severity of shock. Circulation. 1969 Jan;39(1):131-8.

24. Akata T, Kanna T, Yoshino J, Higashi M, Fukui K, Takahashi S. Reliability of fingertip skin-surface temperature and its related thermal measures as indices of peripheral perfusion in the clinical setting of the operating theatre. Anaesth Intensive Care. 2004 Aug;32(4):519-29.

25. Rubinstein EH, Sessler DI. Skin-surface temperature gradients correlate with fingertip blood flow in humans. Anesthesiology. 1990 Sep;73(3):541-5.

26. House JR, Tipton MJ. Using skin temperature gradients or skin heat flux measurements to determine thresholds of vasoconstriction and vasodilatation. Eur J Appl Physiol. 2002 Nov;88(1-2):141-5.

27. Creteur J, Carollo T, Soldati G, Buchele G, De Backer D, Vincent JL. The prognostic value of muscle $\mathrm{StO} 2$ in septic patients. Intensive Care Med. 2007 Sep;33(9):1549-56.

28. Gomez H, Torres A, Polanco P, Kim HK, Zenker S, Puyana JC. et al. Use of non-invasive NIRS during a vascular occlusion test to assess dynamic tissue $\mathrm{O}(2)$ saturation response. Intensive Care Med. 2008 Sep;34(9):1600-7.

29. Mulier KE, Skarda DE, Taylor JH, Myers DE, McGraw MK, Gallea BL. et al. Near-infrared spectroscopy in patients with severe sepsis: Correlation with invasive hemodynamic measurements. Surg Infect (Larchmt). 2008 Oct;9(5):515-9.

30. Shapiro NI, Arnold R, Sherwin R, O’Connor J, Najarro G, Singh $\mathrm{S}$. et al. The association of near-infrared spectroscopy-derived tissue oxygenation measurements with sepsis syndromes, organ dysfunction and mortality in emergency department patients with sepsis. Crit Care. 2011;15(5):R223.

31. Colin G, Nardi O, Polito A, Aboab J, Maxime V, Clair B. et al. Masseter tissue oxygen saturation predicts normal central venous oxygen saturation during early goal-directed therapy and predicts mortality in patients with severe sepsis. Crit Care Med. 2012 Feb;40(2):435-40.

32. Galvin EM, Niehof S, Verbrugge SJ, Maissan I, Jahn A, Klein J. et al. Peripheral flow index is a reliable and early indicator of regional block success. Anesth Analg. 2006 Jul;103(1):239,43, table of contents.

33. Biais M, Cottenceau V, Petit L, Masson F, Cochard JF, Sztark
F. Impact of norepinephrine on the relationship between pleth variability index and pulse pressure variations in ICU adult patients. Crit Care. 2011 Jul 12;15(4):R168.

34. Lima AP, Beelen P, Bakker J. Use of a peripheral perfusion index derived from the pulse oximetry signal as a noninvasive indicator of perfusion. Crit Care Med. 2002 Jun;30(6):1210-3.

35. van Genderen ME, Lima A, Akkerhuis M, Bakker J, van Bommel J. Persistent peripheral and microcirculatory perfusion alterations after out-of-hospital cardiac arrest are associated with poor survival. Crit Care Med. 2012 Aug;40(8):2287-94.

36. Lima A, van Genderen ME, Klijn E, Bakker J, van Bommel J. Peripheral vasoconstriction influences thenar oxygen saturation as measured by near-infrared spectroscopy. Intensive Care Med. 2012 Apr;38(4):606-11.

37. Futier E, Christophe S, Robin E, Petit A, Pereira B, Desbordes J. et al. Use of near-infrared spectroscopy during a vascular occlusion test to assess the microcirculatory response during fluid challenge. Crit Care. 2011;15(5):R214.

38. Hernandez G, Pedreros C, Veas E, Bruhn A, Romero C, Rovegno $\mathrm{M}$. et al. Evolution of peripheral vs metabolic perfusion parameters during septic shock resuscitation. A clinical-physiologic study. J Crit Care. 2012 Jun;27(3):283-8.

39. den Uil CA, Caliskan K, Lagrand WK, van der Ent M, Jewbali LS, van Kuijk JP. et al. Dose-dependent benefit of nitroglycerin on microcirculation of patients with severe heart failure. Intensive Care Med. 2009 Nov;35(11):1893-9.

40. Boerma EC, Kuiper MA, Kingma WP, Egbers PH, Gerritsen RT, Ince C. Disparity between skin perfusion and sublingual microcirculatory alterations in severe sepsis and septic shock: A prospective observational study. Intensive Care Med. 2008 Jul;34(7):1294-8.

\section{ROLE OF EVALUATION OF PERIPHERAL PERFUSION IN CLINICAL PRACTICE}

A. Pranskūnas, E. Šalčiūtè, Ž. Pranskūnienė, N. Balčiūnienė, E. Šneider

Key words: peripheral perfusion, noninvasive monitoring, subjective clinical assessment, capillary refill time, temperature gradient, peripheral perfusion index

\section{Summary}

Monitoring of peripheral perfusion is based on the concept that the peripheral circulation during shock is the first to deteriorate and the last to be restored. In this way, observing the skin and muscles perfusion, we can early suspect derangement of systemic hemodynamic. In this review article we described the simple, commonly used in clinical practice, non-invasive methods for evaluation of peripheral perfusion and offered clinical studies which shows their relationship with outcomes and organ function abnormalities.

Correspondence to: a.pranskunas@gmail.com

Gauta 2014-04-07 